\title{
Gambaran Karakteristik Ibu Hamil pada Persalinan Preterm di RSUP Dr. M. Djamil Padang Tahun 2012
}

\author{
Verdani Leoni Edrin ${ }^{1}$, Ariadi $^{2}$, Lili Irawati ${ }^{3}$
}

\begin{abstract}
Abstrak
Angka kematian bayi di Indonesia menurut Survei Demografi dan Kesehatan Indonesia 2002-2003 sebanyak $57 \%$ terjadi pada umur dibawah 1 bulan. Persalinan preterm merupakan salah satu penyebab kematian bayi. Tujuan penelitian ini adalah untuk mengetahui gambaran karakteristik ibu hamil pada persalinan preterm di RS. Dr. M. Djamil Padang pada tahun 2012. Ini merupakan penelitian deskriptif dengan mengambil data bulan Januari - Desember 2012. Populasi dalam penelitian ini adalah seluruh ibu yang melahirkan preterm sebanyak 72 orang. Sampel yang digunakan adalah total populasi. Data yang dikumpulkan adalah data sekunder. Alat ukur dalam penelitian ini adalah checklist dengan melihat catatan rekam medik pasien, analisis yang di gunakan adalah univariat. Hasil penelitian didapatkan persalinan preterm yang terbanyak adalah ibu hamil berusia $20-35$ tahun $(65,28 \%)$, paritas risiko tinggi $(55,56 \%)$, jarak persalinan $<2$ tahun $(61,11 \%)$, memiliki pendidikan tinggi $(80,56 \%)$, mengalami anemia $(76,39 \%)$, dan tidak melakukan kunjungan antenatal dengan lengkap (72,22\%). Kesimpulan yang dapat diambil dari penelitian ini adalah bahwa persalinan preterm dapat dipengaruhi oleh faktor usia, paritas, jarak persalinan, pendidikan, anemia dan tingkat kunjungan antenatal.
\end{abstract}

Kata kunci: persalinan preterm, karakteristik ibu hamil, faktor risiko persalinan preterm

\section{Abstract}

Indonesia infant mortality rate in Indonesia Demographic and Health Survey 2002 - 2003 occurs in as many as $57 \%$ under the age of 1 month. Preterm labor is one of the causes of infant mortality. The purpose of this study was to know the characteristic of pregnant women in preterm labor at Dr. M. Djamil Padang Hospital in 2012. This research used a descriptive method based on the data from January to December 2012. The population in this study were all of mother who delivered preterm were 72 people. The sample that had been used was the total value of population. The data that had been gathered was a secondary data. Checklist was used as a measuring intrument based on the medical record of the patient. Univariate was used as an analytical approach. The result shows that most preterm delivery are pregnant women aged 20 - 35 years (65,28\%), high risk parity (55,56\%), birth spacing <2 years $(61,11 \%)$, have a high education (80,56\%), some of them are anemic (76,39\%), and no complete antenatal visits (72,22\%). Conclusion from this study is that preterm labor may be influenced by factors of age, parity, birth spacing, education, anemia, and levels of antenatal visits.

Keywords : preterm labor, characteristics of pregnant women, preterm labor risk factor

Affiliasi penulis : 1. Pendidikan Dokter FK UNAND (Fakultas Kedokteran Universitas Andalas Padang), 2. Bagian Kebidanan FK UNAND, 3. Bagian Fisika FK UNAND.

Korespondensi :Verdani Leoni Edrin, email:

verdani.danileoni@yahoo.com, Telp: 085766358371

\section{PENDAHULUAN}

Angka kematian neonatal masih terhitung tinggi. Sesuai target MDGs (Millenium Development Goals), AKI harus turun sampai 102 per 100.000 kelahiran hidup pada tahun 2015. Angka kematian bayi di Indonesia menurut SDKI 2002 -2003 sebanyak $57 \%$ terjadi pada umur dibawah 1 bulan. Target yang 
ingin dicapai oleh MDGs adalah mengurangi Angka Kematian Bayi (AKB) sebesar dua per tiga dari tahun 1990 yaitu sebesar 20 per 1000 kelahiran hidup. ${ }^{1}$

Salah satu penyebab kematian bayi disebabkan karena persalinan preterm. Persalinan preterm adalah persalinan yang terjadi kurang dari 37 minggu masa kehamilan dan akan menghasilkan bayi dengan berat badan lahir rendah (BBLR) ( $<2500$ gram), dimana bayi belum tumbuh dan berkembang secara sempurna. Kasus persalinan preterm di Indonesia masih terbilang tinggi yaitu sekitar $16 \% .^{2}$ Dari studi pendahuluan yang telah dilakukan peneliti pada tahun 2013 didapatkan keseluruhan persalinan preterm yang terjadi di RSUP. Dr. M. Djamil tahun 2012 adalah 72 $(2,8 \%)$ persalinan preterm dari seluruh persalinan.

Dampak yang ditimbulkan dari persalinan prematur cukup serius. Bayi dapat memiliki gangguan fisik maupun intelektualnya dibandingkan dengan bayi yang dilahirkan dengan waktu yang cukup bulan. ${ }^{3}$ Gangguan respirasi menyebabkan 44\% kematian yang terjadi pada umur kurang dari 1 bulan. Anoksia 12 kali lebih sering terjadi pada bayi preterm dibandingkan pada bayi aterm. Jika berat bayi kurang dari 1000 gram, maka angka kematian naik menjadi 74\%. Perdarahan intrakranial lima kali lebih sering pada bayi preterm dibanding pada bayi aterm. Hal tersebut terjadi karena lunaknya tulang tengkorak dan immaturias jaringan otak, sehingga bayi preterm lebih rentan terhadap kompresi kepala. ${ }^{4}$

Faktor risiko yang mempengaruhi kejadian persalinan preterm adalah usia ibu, paritas, jarak persalinan, tingkat pendidikan, pelayanan antenatal, anemia, merokok, dan minum alkohol. ${ }^{5}$ Kehamilan yang terjadi pada usia dibawah 20 tahun atau diatas 35 tahun cenderung tidak terpenuhinya kebutuhan gizi yang adekuat untuk pertumbuhan janin yang akan berdampak terhadap berat badan lahir bayi. ${ }^{6}$ Semakin tinggi paritas maka kemampuan rahim untuk menyediakan nutrisi bagi ibu dan janin akan terganggu yang akhirnya dapat mengakibatkan terjadinya persalinan preterm. Penelitian Agustiana (2010) didapatkan persalinan preterm lebih sering terjadi pada ibu yang multipara (63,9\%) dibandingkan dengan ibu yang primipara $(36,1 \%){ }^{4}$

Jarak persalinan yang pendek dapat menyebabkan terjadinya persalinan preterm, dikarenakan seorang ibu belum cukup waktu untuk memulihkan kondisi tubuhnya setelah melahirkan sebelumnya, sehingga berisiko terganggunya sistem reproduksi yang akan berpengaruh terhadap berat badan lahir. ${ }^{7}$ Ibu yang berpendidikan Sekolah Dasar (SD) lebih berisiko 3,3 kali untuk melahirkan preterm dibandingkan dengan ibu yang berpendidikan perguruan tinggi. Hal tersebut terjadi karena pendidikan ibu merupakan faktor yang mendasari kepedulian pengambilan keputusan untuk melakukan pemeriksaan selama kehamilan. Sehingga para ibu hamil yang berpendidikan rendah cenderung tidak mengetahui informasi tentang kehamilannya. ${ }^{4}$

Pelayanan antenatal adalah pemeriksaan kehamilan yang harus diikuti oleh ibu hamil dengan upaya koreksi terhadap penyimpangan yang ditemukan dan bertujuan untuk menjaga ibu hamil agar dapat melalui masa kehamilan, persalinan dan nifas dengan baik dan selamat, serta menghasilkan bayi yang sehat. ${ }^{1}$ Anemia adalah gangguan yang paling umum dari kehamilan. Kekurangan zat besi adalah penyebab paling umum dari anemia. ${ }^{8}$ lbu dengan anemia dapat berisiko untuk melahirkan preterm. Hal itu disebabkan karena kurangnya kadar hemoglobin untuk mengikat oksigen yang akhirnya akan mengganggu suplai oksigen pada metabolisme ibu. ${ }^{9}$ Merokok dan mengkonsumsi minuman beralkohol juga akan berefek kepada perkembangan bayi sehingga akan meningkatkan risiko terjadinya persalinan preterm. ${ }^{10}$

RSUP Dr. M. Djamil Padang merupakan rumah sakit rujukan terbesar di Sumatera Barat sehingga sebagian besar kasus patologis dirujuk ke Rumah Sakit untuk medapatkan pertolongan segera. Tujuan penelitian ini adalah untuk melihat hubungan antara faktor risiko ibu hamil dengan kejadian persalinan preterm di RSUP Dr. M. Djamil.

\section{METODE}

Desain penelitian ini adalah deskriptif untuk mengetahui gambaran karakteriktik ibu hamil pada persalinan preterm yang dilakukan dengan melihat status rekam medis ibu hamil dengan persalinan preterm di bagian Obstetri dan Ginekologi RSUP Dr. M. Djamil Padang.

Penelitian dilakukan pada bulan Maret - Juni 2014 di Sub bagian Rekam Medik (Medical Record) di 
RSUP Dr. M. Djamil Padang.Data sekunder tersebut merupakan data dari bulan Januari - Desember 2012.

Populasi sampel penelitian ini adalah semua ibu hamil dengan persalinan preterm di bagian obstetri dan ginekologi RSUP.Dr. M. Djamil Padang dari bulan Januari - Desember 2012.

Teknik pengambilan sampel menggunakan teknik total sampling dengan mengambil seluruh sampel yang memenuhi kriteria inklusi dan eksklusi mulai pada bulan Januari - Desember 2012.

Analisis data pada penelitian ini menggunakan analisis univariat untuk mengetahui distribusi frekuensi persalinan preterm, usia, tingkat pendidikan, jarak persalinan, paritas, tingkat kunjungan antenatal, dan anemia pada ibu hamil yang akan ditampilkan dalam bentuk tabel.

\section{HASIL}

Telah dilakukan penelitian di Instalasi Rekam Medik RSUP Dr. M. Djamil Padang dengan mengumpulkan data sekunder berupa data pasien persalinan preterm yang dirawat di RSUP Dr. M. Djamil Padang sejak 1 Januari 2012 - 31 Desember 2012. Berdasarkan data yang diperoleh, didapatkan 72 orang pasien persalinan preterm di RSUP Dr. M. Djamil Padang selama tahun 2012.

Tabel 1. Distribusi Frekuensi Usia lbu Hamil pada Persalinan Preterm

\begin{tabular}{lcc}
\hline Usia & $\mathbf{f}$ & $\mathbf{( \% )}$ \\
\hline Risiko rendah $(20-35$ tahun) & 47 & 65,28 \\
\hline Risiko tinggi(<20 tahun dan $>35$ tahun) & 25 & 34,72 \\
\hline Total & 72 & 100 \\
\hline
\end{tabular}

Tabel 1 menggambarkan sebagian besar pasien persalinan preterm merupakan usia risiko rendah, yaitu sebanyak 47 orang $(65,28 \%)$. Rata-rata dari usia ibu hamil pada persalinan preterm adalah usia 29,7 tahun, dengan usia minimum 18 tahun dan usia maksimum 42 tahun.
Tabel 2. Distribusi Frekuensi Paritas Ibu Hamil pada Persalinan Preterm

\begin{tabular}{lcc}
\hline Paritas & $\mathbf{f}$ & $(\%)$ \\
\hline Risiko rendah $(1-4)$ & 32 & 44,44 \\
\hline Risiko tinggi $(0$ dan $>4)$ & 40 & 55,56 \\
\hline Total & 72 & 100 \\
\hline
\end{tabular}

Tabel 2 memperlihatkan bahwa ibu hamil dengan persalinan preterm terbanyak berasal dari kelompok paritas berisiko, yaitu 40 orang (55,56\%). Rata-rata paritas ibu hamil pada persalinan preterm adalah 1 anak, dengan paritas minimum 0 anak (nulipara) dan jarak persalinan maksimum 10 anak.

Tabel 3. Distribusi Frekuensi Jarak Persalinan Ibu Hamil pada Persalinan Preterm

\begin{tabular}{lcc}
\hline Jarak Persalinan & $\mathbf{f}$ & $(\%)$ \\
\hline Risiko rendah ( $\geq 2$ tahun) & 28 & 38,89 \\
\hline Risiko tinggi ( $<2$ tahun) & 44 & 61,11 \\
\hline Total & 72 & 100 \\
\hline
\end{tabular}

Dari tabel 3, dapat dilihat bahwa pasien persalinan preterm terbanyak termasuk pada kelompok jarak persalinan risiko tinggi, yaitu 44 orang $(61,11 \%)$. Rata-rata dari jarak persalinan ibu hamil pada persalinan preterm adalah 16 bulan, dengan jarak persalinan minimum 0 bulan dan jarak persalinan maksimum 10 tahun (120 bulan).

Tabel 4. Distribusi Frekuensi Tingkat Pendidikan Ibu Hamil pada Persalinan Preterm

\begin{tabular}{lcc}
\hline Tingkat Pendidikan & $\mathbf{f}$ & $\mathbf{( \% )}$ \\
\hline Tinggi ( $\geq$ SMA) & 58 & 80,56 \\
\hline Rendah (< SMA) & 14 & 19,44 \\
\hline Total & 72 & 100 \\
\hline
\end{tabular}

Tabel 4 memperlihatkan sebagian besar pasien persalinan preterm memiliki pendidikan yang tinggi, yaitu sebanyak 58 orang $(80,56 \%)$. 
Tabel 5. Distribusi Frekuensi Anemia Ibu hamil pada Persalinan Preterm

\begin{tabular}{lcc}
\hline Anemia & $\mathbf{f}$ & $\mathbf{( \% )}$ \\
\hline Tidak Anemia $(\geq 11$ gr\%) & 17 & 23,61 \\
\hline Anemia $(<11$ gr\%) & 55 & 76,39 \\
\hline Total & 72 & 100 \\
\hline
\end{tabular}

Dari tabel 5, dapat dilihat bahwa sebagian besar pasien persalinan preterm mengalami anemia, yaitu sebanyak 55 orang (76,39\%). Rata-rata kadar hemoglobin ibu hamil pada persalinan preterm adalah 9,4 gr\%, dengan kadar hemoblobin minimum 7,2 gr\% dan kadar hemoglobin maksimum 12 gr\%.

Tabel 6. Distribusi Frekuensi Kunjungan Antenatal lbu hamil pada Persalinan Preterm

\begin{tabular}{lcc}
\hline Kunjungan Antenatal & $\mathbf{f}$ & $\mathbf{( \% )}$ \\
\hline Lengkap & 20 & 27,78 \\
Tidak lengkap & 52 & 72,22 \\
Total & 72 & 100 \\
\hline
\end{tabular}

Tabel 6 diatas memperlihatkan bahwa sebagian besar pasien persalinan preterm tidak melakukan kunjungan antenatal dengan lengkap (K1 dan atau K4 tidak dilaksanakan), yaitu sebanyak 52 orang $(72,22 \%)$.

Usia ibu hamil yang memiliki usia berisiko tinggi ( $<20$ tahun dan $>35$ tahun ) sebanyak 34,72\% dan ibu hamil yang memiliki usia berisiko rendah (20 35 tahun) sebanyak 65,28\%. Hasil ini sesuai dengan penelitian Trihardiani (2011) yang menyatakan bahwa persalinan preterm banyak terjadi pada usia $20-35$ tahun, yaitu sebanyak $81,6 \%$, dan yang berusia $<20$ tahun dan $>35$ tahun sebanyak $18,4 \%{ }^{7}$

Ibu hamil usia <20 tahun merupakan usia yang berisiko karena kondisi panggul yang belum berkembang secara optimal dan kondisi mental yang belum siap menghadapi kehamilan dan menjalankan peran sebagai ibu. ${ }^{11}$ Ibu hamil usia >35 tahun juga merupakan usia yang berisiko. lbu yang berumur $>35$ tahun mulai menunjukan pengaruh proses penuaannya, seperti munculnya penyakit seperti hipertensi dan diabetes melitusyang dapat menghambat masuknya makanan janin melalui plasenta. ${ }^{12}$

Berdasarkan hasil penelitian diatas didapatkan usia ibu hamil dengan risiko rendah memiliki jumlah yang lebih banyak, hal tersebut terjadi karena di RSUP Dr. M. Djamil pada tahun 2012, persalinan preterm terbanyak berasal dari kelompok usia $20-35$ tahun, sehingga didapatkan usia resiko rendah yang lebih banyak dibandingkan dengan usia risiko tinggi. Selain itu, persalinan preterm juga dapat disebabkan oleh ibu yang memiliki gizi kurang dan memiliki aktifitas yang berat.

Penelitian paritas ibu hamil ditemukan kasus persalinan preterm paling banyak terjadi pada kelompok paritas dengan risiko tinggi (55,56\%), sedangkan paritas risiko rendah sebanyak 44,44\%. Hasil penelitian ini sama dengan penelitian Festy, namun angka paritas dengan risiko tinggi yang didapatkan lebih tinggi dibandingkan dengan penelitian yang saat ini dilakukan, yaitu sebanyak $88,2 \%$ dan paritas risiko rendah sebanyak $11,8 \%{ }^{13}$

Terjadinya persalinan kurang bulan, pada nulipara (paritas 0 belum pernah melahirkan sama sekali) terutama yang berumur belasan tahun diduga disebabkan kehamilan pertama merupakan pengalaman pertama bagi ibu untuk melahirkan, hal itu akan menyebabkan timbulnya beberapa penyulit kehamilan. Penyulit kehamilan ini dapat merupakan ketuban pecah dini, infeksi selaput ketuban, gemeli, perdarahan antepartum ataupun stres yang berhubungan dengan lingkungan yang memungkinkan untuk terjadinya persalinan kurang bulan, baik secara persalinan spontan maupun buatan. ${ }^{14}$ Paritas lebih dari empat juga berisiko mengalami komplikasi serius, seperti perdarahan dan infeksi yang akan mengakibatkan adanya kecenderungan bayi lahir dengan kondisi

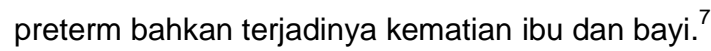

Dari hasil penelitian jarak persalinan ibu hamil, ditemukan bahwa sebagian besar ibu hamil memiliki jarak persalinandengan risiko tinggi, yaitu sebanyak 44 orang $(61,11 \%)$, sementara ibu hamil yang memiliki jarak persalinandengan risiko rendah berjumlah 28 orang $(38,89 \%)$. Hasil penelitian ini sesuai dengan penelitian Sistiarani (2008) yang mendapatkan bahwa ibu yang mempunyai jarak persalinan $<2$ tahun, sebanyak $78,2 \%$, sementara ibu yang mempunyai jarak persalinan $\geq 2$ tahun, sebanyak $21,7 \%$.

Jarak persalinan $<2$ tahun akan menyebabkan seorang ibu belum cukup waktu untuk memulih- 
kan kondisi tubuhnya setelah melahirkan sebelumnya. Ibu hamil dalam kondisi tubuh kurang sehat ini merupakan salah satu faktor penyebab kematian ibu dan bayi yang dilahirkan serta risiko terganggunya sistem reproduksi. Ibu hamil yang jarak kelahirannya kurang dari dua tahun, kesehatan fisik dan kondisi rahimnya masih membutuhkan istirahat yang cukup. Terlalu dekat jarak kehamilan adalah jarak kehamilan antara satu dengan berikutnya kurang dari 2 tahun atau 24 bulan. Pada ibu dengan jarak kehamilan <24 bulan kondisi rahim ibu belum pulih dan risiko kehamilan pada jarak <24 bulan adalah persalinan preterm. $^{11}$

Hasil penelitian tentang tingkat pendidikan, dapat dilihat bahwa sebagian besar pasien persalinan preterm berasal dari pendidikan yang tinggi, yaitu sebanyak 58 orang $(80,56 \%)$ dan pasien persalinan preterm yang berasal dari pendidikan rendah sebanyak 14 orang $(19,44 \%)$. Hal ini sesuai dengan penelitian Agustiana yang menyatakan bahwa lebih banyak ibu hamil berpendidikan tinggi (64,2\%) yang melahirkan preterm, dibandingkan dengan ibu hamil yang berpendidikan rendah (35,6\%). ${ }^{4}$

Dictionory of Education menyebutkan bahwa pendidikan adalah proses dimana seseorang mengembangkan kemampuan sikap dan bentukbentuk tingkah laku lainnya didalam masyarakat dimana ia hidup, bersosialisasi dimana orang dihadapkan pada pengaruh lingkungan yang terpilih dan terkontrol (khususnya yang datang dari sekolah) sehingga dia dapat memperoleh, mengalami perkembangan kemampuan sosial dan kemampuan individu yang optimum. ${ }^{13}$ Tingkat pendidikan merupakan faktor yang mendasari pengambilan keputusan dan hasil persalinan juga ditunjang oleh tingkat pengetahuan ibu tentang kesehatan, lingkungan, ekonomi, interaksi dengan tenaga kesehatan dan kesadaran ibu hamil itu sendiri. ${ }^{15}$ Beberapa ibu hamil yang sudah memiliki pengetahuan hanya baru memeriksakan kehamilan jika merasa mual dan muntah yang sangat mengganggu. Kurangnya dukungan dari keluarga juga mempengaruhi kesadaran ibu hamil dalam memeriksakan kehamilannya. ${ }^{16}$

Penelitian ini mendapatkan bahwa ibu hamil dengan pendidikan tinggi memiliki jumlah terbanyak, hal tersebut terjadi oleh karena ibu hamil yang mengalami persalinan preterm di RSUP Dr. M. Djamil pada tahun 2012 terbanyak berasal dari tingkat pendidikan yang tinggi.

Sebagian besar ibu hamil dengan persalinan preterm lebih banyak yang mengalami anemia, yaitu sebanyak $76,39 \%$ dan ibu hamil dengan persalinan preterm yang tidak mengalami anemia sebanyak $23,61 \%$. Hasil penelitian ini berbeda dengan penelitian Trihardiani (2011) yang menyatakan bahwa ibu dengan persalinan preterm yang mengalami anemia sebanyak $42,40 \%$, sedangkan yang tidak mengalami anemia sebanyak $57,6 \%{ }^{7}$

Kelahiran preterm dapat terjadi melalui beberapa mekanisme, yaitu melalui infeksi maternal, hipoksia dan stress oksidatif. Hal tersebut merupakan tiga mekanisme biologis utama terjadinya persalinan preterm. Kekurangan zat besi dapat meningkatkan risiko infeksi ibu dan hemoglobin yang rendah dapat menyebabkan keadaan hipoksia kronis yang dapat menginduksi stres ibu dan janin. Sistem kekebalan tubuh akan diaktifkan dengan adanya infeksi, peradangan, atau kortisol yang dirilis setelah respon stres, kemudian axis hipotalamus-hipofisis - adrenal ibu atau janin akan diaktifkan. Keadaan ini dapat memicu terjadinya persalinan dan akhirnya mengakibatkan persalinan preterm. Pada akhirnya, kekurangan zat besi juga dapat meningkatkan stres oksidatif yang mengakibatkan kerusakan eritrosit dan unit fetoplasenta. $^{17}$

Tingkat kunjungan antenatal sebagian besar pasien persalinan preterm ternyata tidak melakukan kunjungan antenatal dengan lengkap (K1 dan atau K4 tidak dilaksanakan), yaitu sebanyak 52 orang $(72,22 \%)$, sementara pasien persalinan preterm yang melakukan kunjungan antenatal dengan lengkap dan memenuhi standar pemeriksaan (K1 dan K4 dilaksanakan), sebanyak 20 orang $(27,78 \%)$. Hasil ini sesuai dengan penelitian Agustiana (2010) yang menyatakan lebih banyak ibu hamil yang tidak melakukan kunjungan antenatal lengkap (60,6\%) dibandingkan dengan ibu hamil yang melakukan kunjungan antenatal sesuai standar $(39,4 \%){ }^{4}$ Kunjungan antenatal yang ideal minimal adalah 4 kali kunjungan (K4) selama kehamilan, yaitu 1 kali pada trimester satu, 1 kali pada trimester dua, dan 2 kali pada trimester tiga. ${ }^{18}$ Pada penelitian ini banyak ibu 
hamil yang hanya melakukan kunjungan antenatal sebanyak 1-3 kali saja atau bahkan tidak melakukannya sama sekali.

Pelayanan antenatal adalah pelayanan kesehatan yang diberikan kepada ibu selama masa kehamilannya sesuai dengan standar pelayanan antenatal yang mencakup anamnesis, pemeriksaan fisik umum dan kebidanan, pemeriksaan laboratorium atas indikasi tertentu serta indikasi dasar dan khusus. Selain itu aspek yang lain yaitu penyuluhan, Komunikasi, Informasi dan Edukasi (KIE), motivasi ibu hamil dan rujukan. Pelayanan antenatal melalui konseling dan penyediaan pelayanan merupakan medium yang tidak hanya mempromosikan perilaku kesehatan dan gizi yang baik selama hamil, tetapi juga mengidentifikasikan dan merujuk kehamilan risiko tinggi, termasuk penanganan persalinan preterm yang dialami oleh ibu hamil. Kunjungan antenatal sesuai dengan ketentuan minimal merupakan hal yang sangat penting karena dengan melakukan kunjungan antenatal, berbagai faktor risiko dan komplikasi bisa dapat segera diketahui seawal mungkin sehingga dapat mengurangi faktor risiko untuk terjadinya persalinan preterm. ${ }^{1}$

\section{KESIMPULAN}

1. Ibu hamil dengan risiko rendah lebih banyak mengalami persalinan preterm.

2. Ibu hamil dengan paritas risiko tinggi lebih banyak mengalami persalinan preterm.

3. Ibu hamil dengan jarak persalinan risiko tinggi lebih banyak mengalami persalinan preterm.

4. Ibu hamil dengan tingkat pendidikan tinggi lebih banyak mengalami persalinan preterm.

5. Ibu hamil dengan anemia lebih banyak mengalami persalinan preterm.

6. Ibu hamil dengan kunjungan antenatal tidak lengkap lebih banyak mengalami persalinan preterm.

\section{DAFTAR PUSTAKA}

1. Sistiarani C. Faktor maternal dan kualitas pelayanan antenatal yang berisiko terhadap kejadian berat badan lahir rendah (BBLR) di RSUD Banyumas (thesis). Semarang: Universitas Diponegoro; 2008.

2. Kementrian Kesehatan Republik Indonesia. Profil kesehatan Indonesia 2011. Jakarta; 2011.

3. Cunningham FG, Schorge JO, Schaferr JI, halforson RM, Hoffman BL. Obstetri William, Edisi ke-21. Jakarta: EGC; 2006.

4. Agustiana T. Faktor-faktor yang berhubungan dengan persalinan preterm di indonesia tahun 2010 (analisis data Riskesdas tahun 2010) (skripsi). Jakarta: Universitas Indonesia; 2010.

5. Offiah I, Keelin O, Louise K. Clinical risk factors for preterm birth. preterm birth: mother and child; 2010. (diunduh 26 Februari 2013). Tersedia dari: URL: HYPERLINK http://www.intechopen.com/

6. Irmawati. Pengaruh anemia ibu hamil dengan terjadinya persalinan preterm di rumah sakit ibu dan anak Budi Kemuliaan Jakarta (thesis). Jakarta: Universitas Indonesia; 2010.

7. Trihardiani I. Faktor risiko kejadian berat badan lahir rendah di wilayah puskesmas Singkawang Timur dan Utara. Semarang: Universitas Diponegoro; 2011.

8. Parker JA, Filipa B, Simon JS, Helen S, Sally $\mathrm{H}$, Carolyn JD, et al. Gaps in the evidence for prevention and treatment of maternal anemia: review of systematic review. BMC Pregnancy and Childbirth. 2012;12:56 (diunduh 21 Maret 2013). Tersedia dari: URL: HYPERLINK http://www.biomedcentral.com/14712393/12/5

9. Simanjuntak NA. Hubungan anemia pada ibu hamil dengan kejadian bayi berat lahir rendah (BBLR) di badan pengelola rumah sakit umum (BPRSU) Rantau Prapat kabupaten Labuhan Batu tahun 2008 (skripsi). Medan: Universitas Sumatera Utara;2009.

10. Sujiyatini, Mufdlilah, Asri H. Asuhan patologi kebidanan. Jakarta: Nuha Medika; 2009.

11. BKKBN. Keluarga Berencana dan Kontrasepsi. Jakarta: Pustaka Sinar Harapan: 2007. 
12. Proverawati A, Ibrahin, Siti M. Nutrisi janin dan ibu hamil. Yogyakarta: Nuha Medika; 2010.

13. Festy $P$. Analisis faktor risiko pada kejadian berat badan lahir rendah di kabupaten sumenep (skripsi). Surabaya: Fakultas IImu Kesehatan Universitas Muhammadiyah; 2010.

14. Imron R, Amrina O. Penyebab persalinan preterm. Jurnal Keperawatan. 2012;8(2).

15. Damayanti E. Hubungan tingkat pengetahuan ibu hamil tentang risiko tinggi kehamilan dengan kepatuhan kunjungan antenatal caredi RSUD Pandan Arang Boyolali.
Surakarta: Fakultas IImu Kesehatan Universitas Muhammadiyah; 2008.

16. Maulidayanti H, Asiah B. Gambaran implementasi program jaminan persalinan di puskesmas Batua Kota Makassar. Makassar: Fakultas Kesehatan Masyarakat Universitas Hasanuddin; 2009.

17. Zhang Q, Ananth CV, Li Z, Smulian JC. Maternal Kementrian Kesehatan Republik Indonesia. International Journal of Epidemiology; 2009 (diunduh 9 Juni 2014). Tersedia dari: URL: HYPERLINK http://m.ije.oxfordjournals.org/

18. Pantiwati I, Saryono S. Asuhan kebidanan i. Yogyakarta: Nuha Medika; 2010. 